Article

\title{
Mercury Contamination of Cattle in Artisanal and Small-Scale Gold Mining in Bombana, Southeast Sulawesi, Indonesia
}

\author{
Basri $^{1,2}$ (D), Masayuki Sakakibara ${ }^{1,3, *}$, Koichiro Sera $^{4}$ and Idham Andri Kurniawan ${ }^{3}$ \\ 1 Graduate School of Science and Engineering, Ehime University, 2-5 Bunkyo-cho, \\ Matsuyama, Ehime Prefecture 790-8577, Japan; basrikesmas@gmail.com \\ 2 Makassar School of Health Science (Sekolah Tinggi Ilmu Kesehatan Makassar), Jl. Maccini Raya No. 197, \\ Makassar 90231, Indonesia \\ 3 Faculty of Collaborative Regional Innovation, Ehime University, 3 Bunkyo-cho, \\ Matsuyama, Ehime Prefecture 790-8577, Japan; idham@sci.ehime-u.ac.jp \\ 4 Cyclotron Research Centre, Iwate Medical University, 348-58 Tomegamori, Takizawa, \\ Iwate 020-0173, Japan; ksera@iwate-med.ac.jp \\ * Correspondence: sakakibara.masayuki.mb@ehime-u.ac.jp; Tel.: +81-899-279-649
}

Received: 2 August 2017; Accepted: 11 December 2017; Published: 14 December 2017

\begin{abstract}
The industrial mining sector is one of the main contributors to environmental damage and toxic metal pollution, although some contamination originates from natural geological sources. Due to their position at the top of the food chain, cattle tend to bioaccumulate mercury $(\mathrm{Hg})$ in their bodies. We used analyses of cattle hair samples to investigate $\mathrm{Hg}$ contamination in cattle farmed within and outside of an artisanal and small-scale gold-mining area in Bombana, Southeast Sulawesi, Indonesia. We also examined the factors that might have influenced the toxicity, such as the environmental conditions, sex, and age of the cattle. A total of 63 hair samples were analyzed by particle-induced X-ray emission spectrometry. The mean $\mathrm{Hg}$ concentration was significantly higher in hair from cattle farmed within the artisanal and small-scale gold mining area (11.44 $\mu \mathrm{g} / \mathrm{g}$ hair) than in those farmed outside the area $(2.89 \mu \mathrm{g} / \mathrm{g}$ hair, $p<0.05)$. A possible cause of this is contamination by mercury persistent in terrestrial food chain. The results indicates that the level of toxic metals such as $\mathrm{Hg}$ need to be controlled in food sources to protect human health, especially in Bombana, Indonesia.
\end{abstract}

Keywords: mercury contamination; cattle; artisanal and small-scale gold mining; terrestrial food chain; Bombana

\section{Introduction}

Although the industrial and agricultural sectors are largely responsible for environmental degradation and toxic metal pollution, some contamination comes from natural geological sources, and these can be evaluated through geochemical factor analysis [1-3]. Mercury is a highly toxic element, and is released into the environment as metallic $\mathrm{Hg}[4,5]$. $\mathrm{Up}$ to $\sim 80 \%$ is derived from human activities, such as burning fossil fuels, mining, smelting, and burning waste; with the remainder primarily from volcanoes and forest fires [6-8]. The artisanal and small-scale gold mining (ASGM) sector, as informal (illegal) mining, is responsible for $37 \%$ of all anthropogenic mercury emissions in the environment. Mercury-based gold extraction has resulted in increased levels of various forms of natural mercury $(\mathrm{Hg})$, such as elemental, organic, and inorganic $\mathrm{Hg}$. As a persistent contaminant, $\mathrm{Hg}$ is transported easily and biomagnifies through the food web without noticeable biological function [9], causing mortality, reproductive failure, and other health effects in animals [10,11]. Methylmercury tends to accumulate and biomagnify in the bodies of herbivores at the second trophic level of the terrestrial food chain $[12,13]$. 
Bioaccumulation of metals in the food chain process occurs in all animals, including food animals such as fish and cattle, and also in humans [2,14]. Diet in large mammals is the main route for metal accumulation, causing heavy metal accumulation in the kidneys, liver, bones, hair, and blood of these mammals. Cows, as large mammals, often swallow grass or other contaminated vegetation, drinking water, and small amounts of contaminated soil, although there is a possibility of exposure to metals through inhalation or treatment. The presence of $\mathrm{Hg}$ in meat and meat products is a major concern for public health and food security itself, causing widespread concern about public health [3]. Therefore, the levels of these toxic metals in foodstuffs need to be controlled, and this is of particular interest in Bombana.

In general, the toxic effect of $\mathrm{Hg}$ depends on the form and dose of $\mathrm{Hg}$, the exposure duration, and the ingestion route. Exposure to $\mathrm{Hg}$ has been found to be toxic to both humans and animals [6]. There are similarities and differences in the toxic effects of the various forms of $\mathrm{Hg}[15,16]$. Organic $\mathrm{Hg}$ is the more toxic form, and causes poisoning if ingested [17]. The major targets of toxicity from inorganic and organic $\mathrm{Hg}$ are the kidneys and the central nervous system, respectively. The clinical signs of $\mathrm{Hg}$ poisoning in cattle vary greatly, and include ataxia, neuromuscular incoordination, and renal failure, followed by convulsions and a moribund state $[18,19]$.

Some literature has discussed the accumulation of heavy metals in large mammals, including cattle [20]. Large mammals that are on the second trophic level of the terrestrial food chain ingest contaminated vegetation mixed with small amounts of soil, or contaminated drinking water [21]. However, metal mobility and its availability in the soil determine the risk of metals entering the food chain [22]. As a hypothesis, a possible cause of this is contamination by mercury persistent in terrestrial food chain. This may become a food safety issue in the future, as long-term consumption of contaminated beef can cause $\mathrm{Hg}$ poisoning in humans.

There is concern that feed for livestock is contaminated locally by Hg-based gold processing activities, with implications for toxicity in cattle herds. To date, however, there is no information regarding the $\mathrm{Hg}$ concentration in livestock in Bombana, or in any other region of Sulawesi. In this preliminary study, we collected samples of hair to investigate the level of $\mathrm{Hg}$ contamination in cattle from two regions of Bombana. The three specific objectives of our study were (i) to measure the total $\mathrm{Hg}$ concentrations in hair from cattle, (ii) to investigate whether $\mathrm{Hg}$ residues varied with the age or sex of the cattle, and (iii) to determine whether the gold mining industry was associated with increased levels of total $\mathrm{Hg}$ in cattle.

\section{Materials and Methods}

\subsection{Study Area and Geological Background}

Bombana has two ASGM sites that have expanded progressively over the past ten years [23]. Secondary gold deposits can be found in the Bombana gold mining sites. This type, discovered in the form of alluvial gold, is formed by obtaining gold through a natural process. The oxidation process influences the circulation of water and leads to the disintegration of gold ore constituents. In this location, the alluvial type contains gold granules of excessive size, spread over an area only a few meters wide, are relatively shallowly deposited, and which are explored using large-capacity equipment. The sediments formed in ASGM include mica schist, glaucophane schist, amphibole schist, chlorite schist, jasperoidal chert, genesis schist, marble, and metalimestone. Significant levels of gold production create high levels of income for local miners, and has encouraged the rapid development of the small-scale gold mining industry in a short time.

The number of cattle in the Bombana area increased from 46,686 in 2014 to 54,029 in 2016, and they are currently the most important agricultural animal in this region. Bombana is the largest beef-producing center in Sulawesi, and accounts for about $70 \%$ of Sulawesi's total production. Altogether, there are about 5000 head of cattle in the sub-districts of Rarowatu and North Rarowatu, which have been the focus of the gold mining industry since 2008. In Bombana ASGM areas, cattle are 
directly exposed to $\mathrm{Hg}$ vapor, because they are farmed close to sites where gold is mined and refined. In addition, waste from the mines can contaminate soil, water bodies, and animal feed.

The study was conducted in the Bombana Regency of Southeast Sulawesi, Indonesia (Figure 1), where agriculture is dominated by cattle ranching. We performed sampling in the Rarowatu sub-district, as it contained artisanal and small-scale gold mining (ASGM) development areas that had probably been contaminated with heavy metals, particularly mercury. The sampling area was expanded to the North Rarowatu sub-district to cover non-ASGM areas as a comparison.

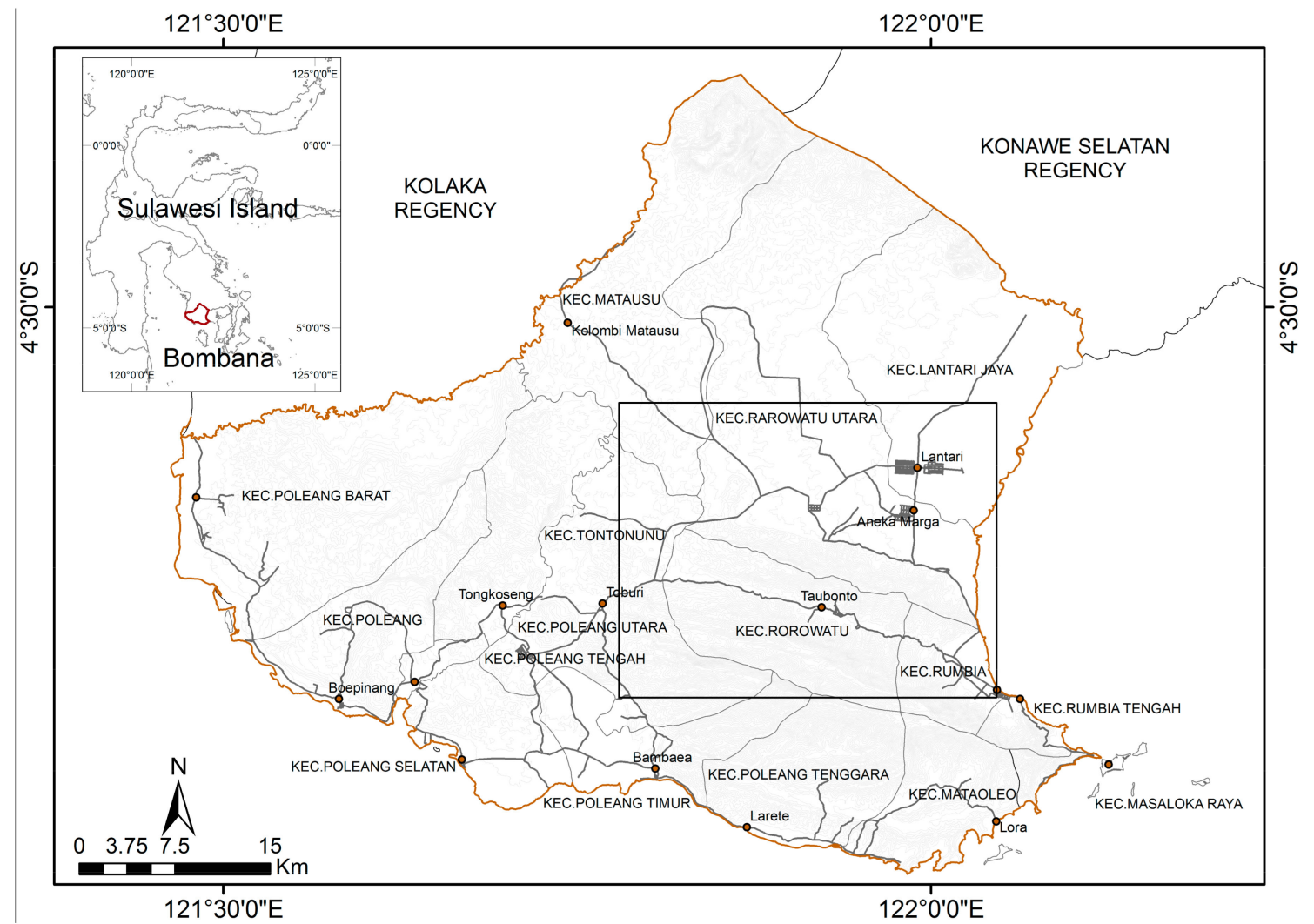

Figure 1. The location of the study (square line).

\subsection{Sample Collection}

To obtain cattle hair for analysis of total mercury (tHg) levels, we collected hair samples from similar numbers of male and female cattle aged 1-15 years, from cattle farmed in the two sampling areas, over the period from August 2016 to March 2017 (Figure 2). We also attempted to determine the factors influencing the toxic levels of $\mathrm{Hg}$ in the samples. Hair samples were taken from cows representing each of the colonies using a non-random approach. The selection of each territory was based on the factors of distance and permitted access from the local community. The cows live in groups and move within a $3 \mathrm{~km}^{2}$ range for food. The sample distribution within the ASGM area was denser than outside of ASGM site. The landscape at the ASGM sites was dominated by tropical savanna hill, while outside the ASGM sites, landscape conditions were widely distributed among rivers, forest edges, and rice field locations. The total area of sampling was about $130 \mathrm{~km}^{2}$. 


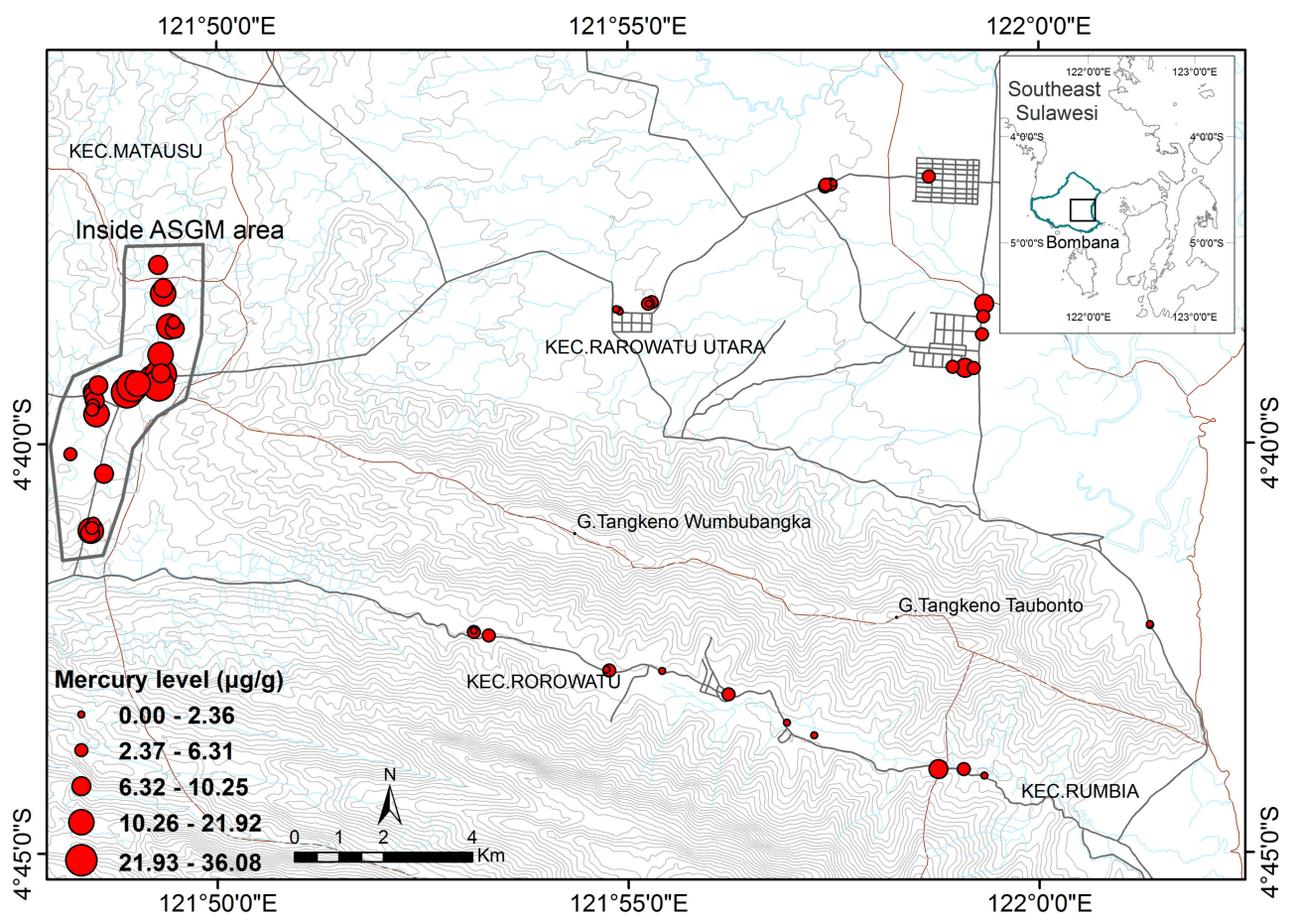

Figure 2. The location of the samples site and distribution of $\mathrm{Hg}$ level.

\subsection{Analytical Method}

The samples were shaken with Milli-Q water $(18.2 \mathrm{M} \Omega / \mathrm{cm})$ in an ultrasonic cleaning bath (Sharp) for $5 \mathrm{~min}$ to remove dust, dirt, bacteria, and other contaminants. The samples were then dried with sterile paper on a clean glass plate for $10 \mathrm{~min}$. The dried samples were stirred in acetone solution (Wako Pure Chemical Industries, Ltd., Osaka, Japan) for $5 \mathrm{~min}$ to remove any organic material that was not water soluble $[6,11]$. The samples were then washed again with Milli-Q water and dried using sterile tissue at room temperature. Several strands of hair were randomly selected from each dried sample and cut into sections that included either the root or the end of the strand. About eight hair samples were attached parallel to the sample holder during preparation of the target. The Environmentally Certified Reference Materials (CRMs) from the National Institute for Environmental Studies was prepared for use in evaluation of accuracy of $\mathrm{tHg}$ of animal hair. The samples were analyzed by particle-induced X-ray emission (PIXE) at the Cyclotron Research Center, Iwate Technical University, Japan, using a proton energy beam of $2.5-3 \mathrm{MeV}$. In this method, the $\mathrm{X}$-ray emissions from the sample that pass through the target area were detected by a $\mathrm{Si}(\mathrm{Li})$ detector. Low-energy X-rays were attenuated by a 300-pm Mylar Mixer filter. Rays of uniform density were combined to have a diameter of $6 \mathrm{~mm}$ with a thick nickel foil and a diffuser in a graphite collimator system. The samples were placed on the target rectangle at an angle of $\sim 35^{\circ}$ to the horizontal beam axis.

\subsection{Data Analysis}

The data sets both within and without the ASGM site were not normally distributed, but had the same variance. We used the Mann-Whitney $U$ test to identify differences in $\mathrm{Hg}$ concentrations in hair from cattle in Rarowatu and North Rarowatu, with reference to sex, age, and sample site. Differences were considered significant for $p$ values $<0.05$. In all statistical analyses, Paleontological Statistic (PAST) Ver. 3.17 and IBM SPSS Statistic 21 Ver. 21.0 [24] were utilized. 


\section{Results}

\subsection{Laboratory Data}

The analytical results are listed in Table 1. Of the 63 samples of hair collected, 34 were taken from cattle farmed within the two ASGM areas, and 29 were from cattle farmed outside the ASGM areas (total female, $n=42$; male, $n=21$ ). Fewer males were sampled, because they are farmed in smaller numbers than females. There was no statistically significant relationship between sex and sampling location $(p>0.05)$. Minimum and maximum ages were the same in both of the sampling sites, inside and outside the ASGM area, and the mean and median ages were higher in the two ASGM sites than outside the sites. Age was significantly different between the two sampling sites $(p<0.05)$.

Table 1. Number, sex, and age of cattle, distribution by location and Hg concentration.

\begin{tabular}{|c|c|c|c|c|c|}
\hline \multirow{2}{*}{\multicolumn{2}{|c|}{ Animal Data }} & & \multicolumn{2}{|c|}{ Sample Location } & \multirow[b]{2}{*}{$\begin{array}{c}\text { Mann-Whitney } \\
U \text { Test }\end{array}$} \\
\hline & & & $\begin{array}{c}\text { Inside of ASGM } \\
\text { Site }(n=34)\end{array}$ & $\begin{array}{l}\text { Outside of ASGM } \\
\text { Site }(n=29)\end{array}$ & \\
\hline \multirow{2}{*}{\multicolumn{2}{|c|}{ Quartile }} & Q1 & 5.20 & 1.03 & \\
\hline & & Q3 & 8.22 & 4.57 & \\
\hline \multicolumn{2}{|c|}{$\begin{array}{l}\mathrm{Hg} \text { levels }(\mu \mathrm{g} / \mathrm{g}) \text { and } \\
\text { sample location }\end{array}$} & $\begin{array}{l}\text { Mean } \pm \text { SD } \\
\text { Median }\end{array}$ & $\begin{array}{c}11.44 \pm 9.52 \\
8.22\end{array}$ & $\begin{array}{l}2.89 \pm 2.45 \\
2.14\end{array}$ & $p(0.000)<0.05 *$ \\
\hline \multicolumn{2}{|c|}{$\begin{array}{l}\text { Age (years) and } \\
\text { sample location }\end{array}$} & $\begin{array}{c}\text { Mean } \pm \text { SD } \\
\text { Median }\end{array}$ & $\begin{array}{c}6.00 \pm 2.90 \\
6\end{array}$ & $\begin{array}{c}4.00 \pm 3.07 \\
3\end{array}$ & $p(0.003)<0.05^{*}$ \\
\hline \multirow{2}{*}{$\begin{array}{c}\text { Hg levels } \\
\text { ( } \mu \mathrm{g} / \mathrm{g}) \text { sex and } \\
\text { sample location }\end{array}$} & $\begin{array}{l}\text { Male } \\
(n=21)\end{array}$ & $\begin{array}{l}\text { Mean } \pm S D \\
\text { Median }\end{array}$ & $\begin{array}{c}10.17 \pm 7.13 \\
7.52\end{array}$ & $\begin{array}{c}2.41 \pm 2.40 \\
1.89\end{array}$ & $p(0.037)<0.05^{*}$ \\
\hline & $\begin{array}{l}\text { Female } \\
(n=42)\end{array}$ & $\begin{array}{c}\text { Mean } \pm \text { SD } \\
\text { Median }\end{array}$ & $\begin{array}{c}11.98 \pm 10.45 \\
8.62\end{array}$ & $\begin{array}{c}3.19 \pm 2.51 \\
3.12\end{array}$ & $p(0.084)>0.05^{* *}$ \\
\hline
\end{tabular}

\subsection{Source of Exposure}

There was a statistically significantly difference in $\mathrm{Hg}$ concentration among hair samples from inside and outside ASGM area with $p<0.05$ (Figure 3). PIXE analysis revealed higher mean and median Hg levels in the hair of animals farmed within the ASGM site than in those farmed outside these areas.

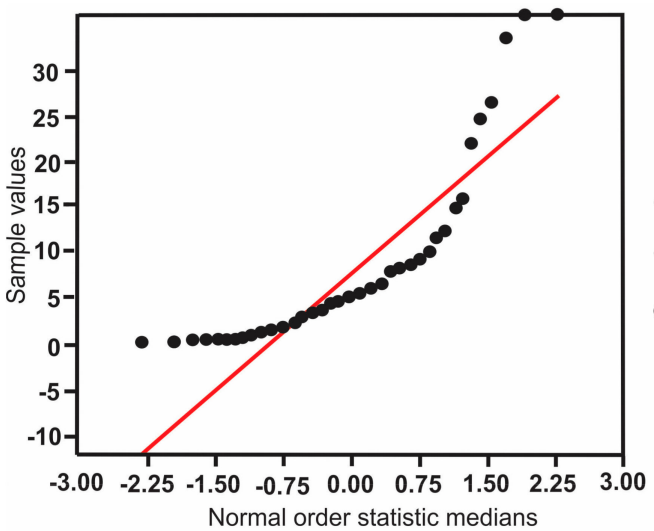

(A)

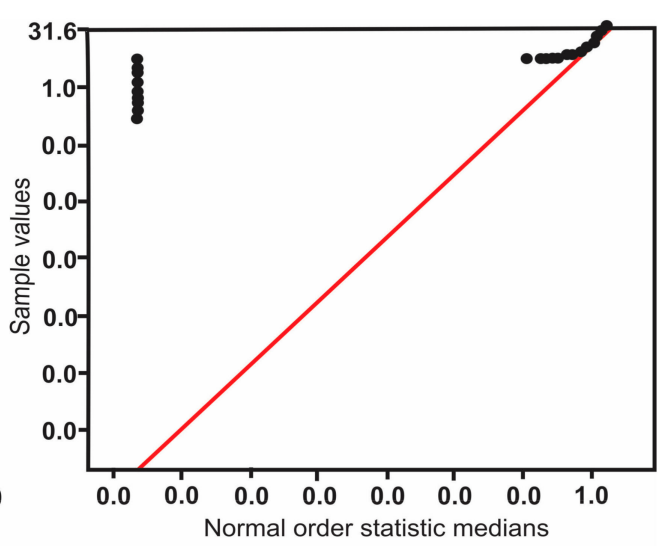

(B)

Figure 3. The normal probability plot of mean $\mathrm{Hg}$ both inside and outside the ASGM areas. (A) Sample values; (B) Logarithm of sample values. 
The mean $\mathrm{Hg}$ concentration in hair from ASGM areas $(n=34 ; 11.44 \mu \mathrm{g} \mathrm{Hg} / \mathrm{g}$ hair) was almost three times that in hair from outside the ASGM areas $(n=29 ; 2.89 \mu \mathrm{g} \mathrm{Hg} / \mathrm{g}$ hair). The Mann-Whitney $U$ test revealed a statistically significant difference in $\mathrm{Hg}$ concentration in hair from inside and outside the ASGM sites $(p<0.05)$ (Figure 4). The values for the two ASGM sites combined were as follows: range, $0.15-36.08 \mu \mathrm{g} / \mathrm{g}$; mean, $7.60 \mu \mathrm{g} / \mathrm{g}$; standard deviation, $8.33 \mu \mathrm{g} / \mathrm{g}$.

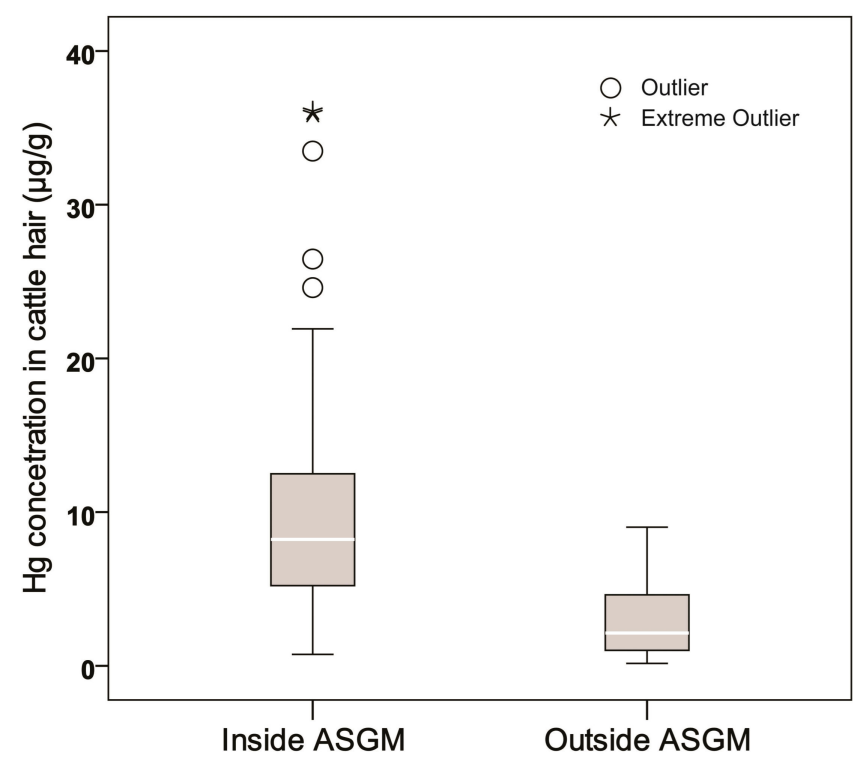

Figure 4. The box plot of $\mathrm{Hg}$ concentration in cattle hair inside and outside the ASGM sites.

There was a statistically significant difference in the age of cattle from inside and outside the ASGM area, with $p<0.05$ (Table 1). Comparison of the rate of $\mathrm{Hg}$ accumulation according to age differences between cattle farmed inside and outside the ASGM areas. In hair from both sampling areas, there was a positive correlation between $\mathrm{Hg}$ concentration and age (Figure 5).

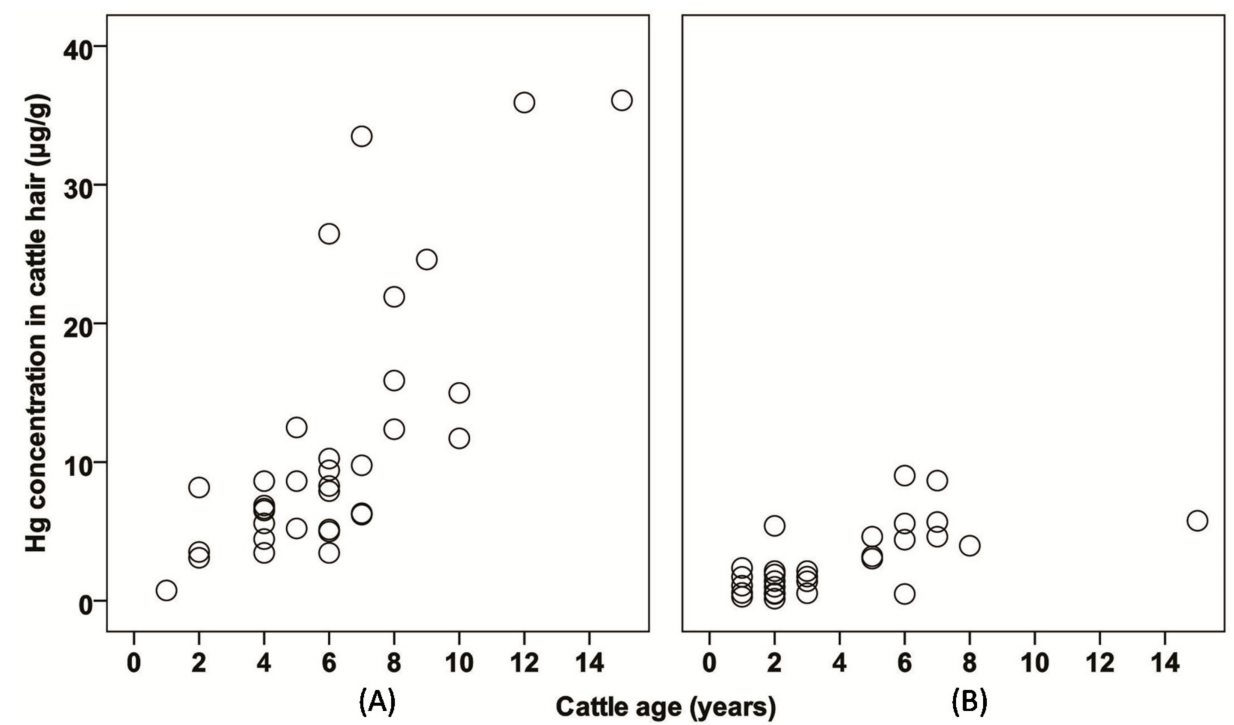

Figure 5. The plots of $\mathrm{Hg}$ concentration with respect to cattle age (A) inside the ASGM area, and (B) outside the ASGM area. 


\subsection{Sex and Hormonal Status}

There was no difference in $\mathrm{Hg}$ accumulation in cattle with respect to the sex of the animal (Figure 6A). The PIXE analytical method showed that the mean $\mathrm{Hg}$ concentration was higher in females than in males ( 8.21 and $6.10 \mu \mathrm{g} / \mathrm{g}$, respectively), but the difference was not statistically significant (Mann-Whitney $U$ test, $p>0.05$; Table 1). The hair concentration was higher in the ASGM areas than in these areas, although significant differences were found in males (Mann-Whitney $U$ test, $p<0.05$; Table 1). Similarly, in the females, Hg concentration was higher in the ASGM area, but there was no significant difference (Figure $6 \mathrm{~B}$ ).

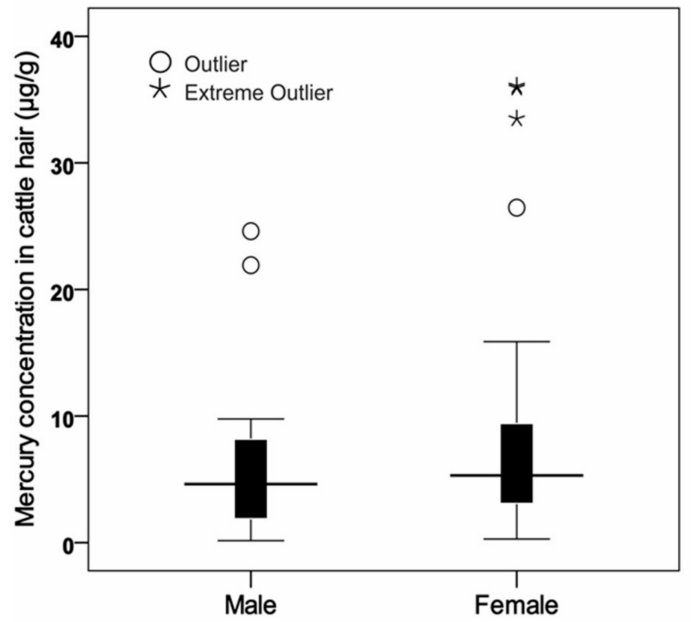

(A)

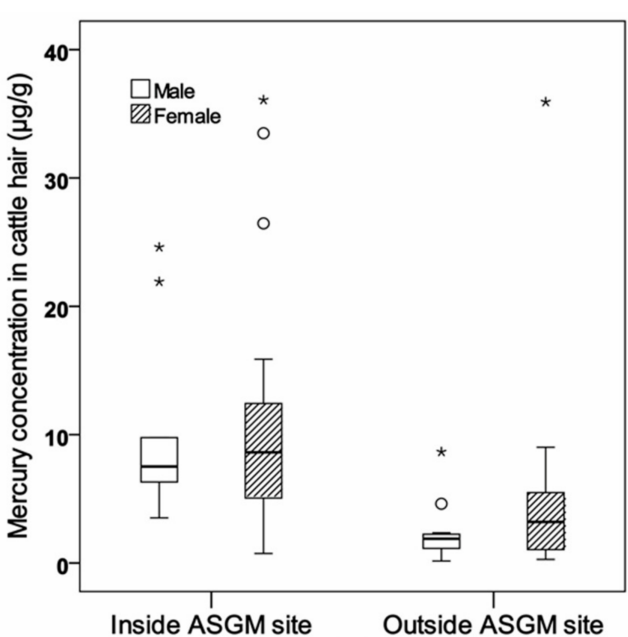

(B)

Figure 6. The box plot of $\mathrm{Hg}$ concentration in cattle hair. (A) $\mathrm{Hg}$ concentration showed no significant difference with respect to animal sex. (B) The concentration of $\mathrm{Hg}$ in females was higher than in males in the two sampling sites.

\section{Discussion}

The response of an animal population to a certain amount of toxicant may differ among individuals, because various factors can modulate the overall toxic response $[25,26]$. Drugs and toxins may be substituted in some kinetic or dynamic interactions when binding to plasma proteins or receptors at the active site of the enzyme involved in biotransformation $[27,28]$. The main factors affecting chemical toxicity in individuals and in populations are breed, age, sex, pathophysiological events, diet composition, environmental conditions, the source, and route of exposure [26]. Here, we examine the influence of environmental conditions, age, maturity, sex, and hormonal status.

\subsection{Environmental Condition}

Previous studies have shown that miners who work in this area have been contaminated with heavy metals, having hair Hg levels as high as $12.82 \mu \mathrm{g} / \mathrm{g}$ [23]. During the gold purification process, gold particles are separated from river sediments, and are extracted from soil ore by washing and filtering; they are then added to liquid $\mathrm{Hg}$ to form an amalgam, which is then fed into a retort or a heated distillation vessel, vaporizing the $\mathrm{Hg}$ and leaving the gold $[29,30]$. Mercury is a critical component of the liquid metal capture process in ASGM; however, some of the $\mathrm{Hg}$ is lost during this process [31-33] and contaminates animals that are farmed nearby [34,35].

\subsection{Age and Maturity}

Because $\mathrm{Hg}$ is thought to bioaccumulate, the concentration of $\mathrm{Hg}$ tends to increase with continued exposure, and thus the age of the animal [20]. This finding indicates that exposure to the residue of 
gold combustion is linked to $\mathrm{Hg}$ accumulation in terrestrial food chains. Younger humans and animals are generally more sensitive to the effects of chemicals than are older humans and animals, for reasons that include differences in absorption rate, plasma protein binding, distribution, biotransformation, and excretion [36].

Previous animal studies have reported an increasing sensitivity to toxins with age, and that the effect was more pronounced in food-producing species that have a long life cycle [37-39]. Pharmacokinetic conditions in groups such as older people, different ethnic groups, and pregnant women will have different pathological effects (e.g., renal and hepatic insufficiency, cardiac dysfunction, and obesity). The xenobiotic cleansing function of the liver and kidneys becomes less effective with increasing age due to a reduction in renal blood flow and glomerular filtration, rather than to a significant reduction in biotransformation capacity [37,40].

\subsection{Sex and Hormonal Status}

Some chemicals may be more toxic to one sex than to the other [41]. Also, variations in response to certain chemicals that are related to physiological differences between the sexes can affect hormonal systems and functions. Biologically, the difference is largely, if not exclusively, related to gonadal hormone secretion. Biological differences between the sexes contribute to many diseases and sex disorders [42,43]. Because male and female might have specific pharmacokinetic and pharmacodynamic differences, sex could affect the response to chemicals [44].

Previous studies have reported $\mathrm{Hg}$ accumulation in terms of the sex of the animal in cattle, studies of other species have shown higher levels of $\mathrm{Hg}$ accumulation in females than males [36]. For example, studies of deer and calves have shown higher levels of $\mathrm{Hg}$ accumulation in females [45]. It is of note that that study found no significant difference in Hg levels in the livers and kidneys between male and female deer. Experimental studies [46] have shown that the excretion and accumulation of $\mathrm{Hg}$ in animal organs are essentially influenced by the status of the reproductive hormones; however, as yet our understanding of the underlying mechanisms is incomplete.

\section{Conclusions}

High concentrations of $\mathrm{Hg}$ were found in the hair of cattle farmed in Bombana, both within and outside of ASGM areas. In the majority of cattle, the levels were much higher than the international regulatory limit for $\mathrm{Hg}$ in animals. The mean $\mathrm{Hg}$ concentration was higher in females than in males, but the difference was not statistically significant. Further, $\mathrm{Hg}$ concentration in cattle hair was positively correlated with the age of the cattle.

The mean $\mathrm{Hg}$ concentrations were highest in the hair of cattle farmed within ASGM areas, and the $\mathrm{Hg}$ concentrations in $80 \%$ of these cattle were potentially toxic. The possible cause of this contamination by mercury persistent in food chain. This contamination and its effects in cattle warrant further investigation.

Acknowledgments: The authors wish to thank the government of Bombana Regency, Indonesia for allowing us to conduct research, and its support with sampling. One author (B) wishes to thank the Indonesian Government for providing a Dikti Scholarship for graduate studies at Ehime University. This research (study) was supported by (and conducted as a part of) the Feasibility Study "Social Acceptance of Regional Innovation for Reducing High-Impact Environmental Pollution", Research Institute for Humanity and Nature (RIHN). This work was supported by JSPS KAKENHI, Grant Number 16H02706 to Masayuki Sakakibara.

Author Contributions: All authors contributed extensively to the work presented in the paper. Basri as principal researcher conducted the analysis and wrote the manuscript, which was undertaken in association with his Ph.D. program. Masayuki Sakakibara, as Ph.D. supervisor, supervised the analyses and edited the manuscript. Koichiro Sera provided the PIXE measurement of hair samples. Idham Andri Kurniawan supported sample preparation and analyses.

Conflicts of Interest: The authors declare no conflict of interest. 


\section{References}

1. Tchounwou, P.B.; Yedjou, C.G.; Patlolla, A.K.; Sutton, D.J. Heavy Metals Toxicity and the Environment. Mol. Clin. Environ. Toxicol. 2012, 101, 133-164. [CrossRef]

2. Barbieri, M.; Sappa, G.; Vitale, S.; Parisse, B.; Battistel, M. Soil control of trace metals concentrations in landfills: A case study of the largest landfill in Europe, Malagrotta, Rome. J. Geochem. Explor. 2014, 143, 146-154. [CrossRef]

3. European Food Safety Authority. Scientific Opinion on the risk for public health related to the presence of mercury and methylmercury in food. Eur. Food Saf. Auth. J. 2012, 10. [CrossRef]

4. Wuana, R.A.; Okieimen, F.E. Heavy Metals in Contaminated Soils: A Review of Sources, Chemistry, Risks and Best Available Strategies for Remediation. ISRN Ecol. 2011, 2011, 1-20. [CrossRef]

5. Singh, R.; Gautam, N.; Mishra, A.; Gupta, R. Heavy metals and living systems: An overview. Indian J. Pharmacol. 2011, 43, 246. [CrossRef] [PubMed]

6. World Health Organization (WHO). Mercury and Health. Available online: http://www.who.int/mediacentre/ factsheets/fs361/en (accessed on 13 December 2017).

7. ATSDR. Public Health Statement for Mercury. Available online: https://www.atsdr.cdc.gov/phs/phs.asp? $\mathrm{id}=112 \& \mathrm{tid}=24$ (accessed on 8 June 2017).

8. US EPA. Basic Information about Mercury. Available online: https://www.epa.gov/mercury/basic-informationabout-mercury (accessed on 8 June 2017).

9. Cristol, D.A.; Brasso, R.L.; Condon, A.M.; Fovargue, R.E.; Friedman, S.L.; Hallinger, K.K.; Monroe, A.P.; White, A.E. The Movement of Aquatic Mercury Through Terrestrial Food Webs. Science 2008, 320, 335. [CrossRef] [PubMed]

10. Hong, Y.-S.; Kim, Y.-M.; Lee, K.-E. Methylmercury exposure and health effects. J. Prev. Med. Public Heal (Yebang Ǔihakhoe chi) 2012, 45, 353-363. [CrossRef] [PubMed]

11. Kim, K.-H.; Kabir, E.; Jahan, S.A. A review on the distribution of $\mathrm{Hg}$ in the environment and its human health impacts. J. Hazard. Mater. 2015, 306, 376-385. [CrossRef] [PubMed]

12. Davis, J.A.; Looker, R.E.; Yee, D.; Marvin-Di Pasquale, M.; Grenier, J.L.; Austin, C.M.; McKee, L.J.; Greenfield, B.K.; Brodberg, R.; Blum, J.D. Reducing methylmercury accumulation in the food webs of San Francisco Bay and its local watersheds. Environ. Res. 2012, 119, 3-26. [CrossRef] [PubMed]

13. Hosseini, M.; Nabavi, S.M.B.; Parsa, Y. Bioaccumulation of trace mercury in trophic levels of benthic, benthopelagic, pelagic fish species, and sea birds from Arvand River, Iran. Biol. Trace Element Res. 2013, 156, 175-180. [CrossRef] [PubMed]

14. Govind, P.; Madhuri, S. Heavy Metals Causing Toxicity in Animals and Fishes. Res. J. Anim. Vet. Fish. Sci. Int. Sci. Congr. Assoc. 2014, 2, 17-23.

15. Jensen, G.; Ruzickova, K. Halting the Child Brain Drain: Why We Need to Tackle Global Mercury Contamination; Health Care Without Harm: Reston, VA, USA, 2006.

16. McClellan, R.O. Chapter 2-Concepts in veterinary toxicology. In Veterinary Toxicology; Elsevier: Oxford, UK, 2012; pp. 8-36. ISBN 9780123859266.

17. Langford, N.J.; Ferner, R.E. Toxicity of mercury. J. Hum. Hypertens. 1999, 13, 651-656. [CrossRef] [PubMed]

18. Saito, K. Lead Poisoning of Steller's Sea Eagle (Haliaeetus pelagicus) and White-tailed Eagle (Haliaeetus albicilla) Caused by the Ingestion of Lead Bullets and Slugs, in Hokkaido, Japan. Ingestion Lead Spent Ammunit. Implic. Wildl. Hum. 2009, 302-309. [CrossRef]

19. Sonne, C.; Alstrup, A.K.O.; Therkildsen, O.R. A review of the factors causing paralysis in wild birds: Implications for the paralytic syndrome observed in the Baltic Sea. Sci. Total Environ. 2012, 416, 32-39. [CrossRef] [PubMed]

20. López Alonso, M.; Benedito, J.L.; Miranda, M.; Castillo, C.; Hernández, J.; Shore, R.F. Mercury concentrations in cattle from NW Spain. Sci. Total Environ. 2003, 302, 93-100. [CrossRef]

21. Miranda, M.; Benedito, J.L.; Blanco-Penedo, I.; López-Lamas, C.; Merino, A.; López-Alonso, M. Metal accumulation in cattle raised in a serpentine-soil area: Relationship between metal concentrations in soil, forage and animal tissues. J. Trace Elements Med. Biol. 2009, 23, 231-238. [CrossRef] [PubMed]

22. Rajakaruna, N.; Boyd, R.S.; Harris, T.B. (Eds.) Plant Ecology and Evolution in Harsh Environments; Nova Science Publishers: Hauppauge, NY, USA, 2014; ISBN 978-1-63321-998-4.

23. Basri; Sakakibara, M.; Sera, K. Current Mercury Exposure from Artisanal and Small-Scale Gold Mining in Bombana, Southeast Sulawesi, Indonesia-Future Significant Health Risks. Toxics 2017, 5, 7. [CrossRef] [PubMed] 
24. Hammer, Ø.; Natural History Museum; University of Oslo. Past 3.x-The Past of the Future. Available online: https:/ / folk.uio.no/ohammer/past/ (accessed on 4 December 2017).

25. Nordberg, G. Effects and dose-response relationships of toxic metals. A report from an international meeting. Scand. J. Work. Environ. Health 1976, 2, 37-43. [CrossRef] [PubMed]

26. Nebbia, C. Factors affecting chemical toxicity. In Veterinary Toxicology; Elsevier: Oxford, UK, 2012 ; pp. $48-61$. ISBN 9780123859266.

27. Van Der Merwe, D.; Gehring, R.; Buur, J.L. Toxicokinetics. In Veterinary Toxicology; Elsevier: Oxford, UK, 2012; pp. 37-47. ISBN 9780123859266.

28. Alavijeh, M.S.; Chishty, M.; Qaiser, M.Z.; Palmer, A.M. Drug metabolism and pharmacokinetics, the blood-brain barrier, and central nervous system drug discovery. NeuroRx 2005, 2, 554-571. [CrossRef] [PubMed]

29. Limbong, D.; Kumampung, J.; Rimper, J.; Arai, T.; Miyazaki, N. Emissions and environmental implications of mercury from artisanal gold mining in north Sulawesi, Indonesia. Sci. Total Environ. 2003, 302, 227-236. [CrossRef]

30. Veiga, M.M.; Baker, R.F.; Fried, M.B.; Withers, D. Protocols for Environmental and Health Assessment of Mercury Released by Artisanal and Small-Scale Gold Miners; Global Mercury Project; UNIDO: Vienna, Austria, 2004; ISBN 92-1-106429-5.

31. De Lacerda, L.D.; Salomons, W. Mercury Contamination of Humans in Gold and Silver Mining Areas, Mercury from Gold and Silver Mining: A Chemical Time Bomb? Springer: New York, NY, USA, 1998; ISBN 3540617248.

32. Li, P.; Feng, X.B.; Qiu, G.L.; Shang, L.H.; Li, Z.G. Mercury pollution in Asia: A review of the contaminated sites. J. Hazard. Mater. 2009, 168, 591-601. [CrossRef] [PubMed]

33. Marsden House, J. The Chemistry of Gold Extraction; Ellis Horwood Limited: Hemel Hempstead, UK, 1992; p. 651.

34. Veiga, M.M.; Maxson, P.A.; Hylander, L.D. Origin and consumption of mercury in small-scale gold mining. J. Clean. Prod. 2006, 14, 436-447. [CrossRef]

35. Wang, Q.; Kim, D.; Dionysiou, D.D.; Sorial, G.A.; Timberlake, D. Sources and remediation for mercury contamination in aquatic systems-A literature review. Environ. Pollut. 2004, 131, 323-336. [CrossRef] [PubMed]

36. Batista, J.; Schuhmacher, M.; Domingo, J.L.; Corbella, J. Mercury in hair for a child population from Tarragona Province, Spain. Sci. Total Environ. 1996, 193, 143-148. [CrossRef]

37. Gupta, R. Veterinary Toxiology—Basic and Clinical Principles; Elsevier: Oxford, UK, 2012; ISBN 9780123859266.

38. Bender, A.D. Drug sensitivity in the elderly. In Drugs and the Elderly; Palgrave Macmillan: London, UK, 1979; pp. 147-153.

39. Crooks, J.; Stevenson, I.H. (Eds.) Drugs and the Elderly; Palgrave Macmillan: London, UK, 1979; ISBN 978-1-349-03815-2.

40. Poggesi, I.; Benedetti, M.S.; Whomsley, R.; Le Lamer, S.; Molimard, M.; Watelet, J.-B. Pharmacokinetics in special populations. Drug Metab. Rev. 2009, 41, 422-454. [CrossRef] [PubMed]

41. ToxTutor-Factors Influencing Toxicity. Available online: https://toxtutor.nlm.nih.gov/03--002.html (accessed on 29 May 2017).

42. Ngun, T.C.; Ghahramani, N.; Sánchez, F.J.; Bocklandt, S.; Vilain, E. The genetics of sex differences in brain and behavior. Front. Neuroendocrinol. 2011, 32, 227-246. [CrossRef] [PubMed]

43. Alomar, M.J. Factors affecting the development of adverse drug reactions (Review article). Saudi Pharm. J. 2014, 22, 83-94. [CrossRef] [PubMed]

44. Soldin, O.P.; Mattison, D.R. Sex differences in pharmacokinetics and pharmacodynamics. Clin. Pharmacokinet. 2009, 48, 143-157. [CrossRef] [PubMed]

45. Khan, A.T.; Forester, D.M. Mercury in white-tailed deer forage in Russell Plantation, Macon County, Alabama. Vet. Hum. Toxicol. 1995, 37, 45-46. [PubMed]

46. Silbergeld, E.K. Chapter 33-Toxicology. Available online: http://www.ilocis.org/documents/chpt33e.htm (accessed on 2 August 2017).

(C) 2017 by the authors. Licensee MDPI, Basel, Switzerland. This article is an open access article distributed under the terms and conditions of the Creative Commons Attribution (CC BY) license (http:/ / creativecommons.org/licenses/by/4.0/). 